\title{
PERAN TOKOH MASYARAKAT DALAM PEMEBERDAYAAN KELUARGA NELAYAN DI DESA PANGANDARAN KECAMATAN PANGANDARAN KABUPATEN PANGANDARAN
}

\author{
Nurhayani Lubis \\ Politeknik Kesejahteraan Sosial (Poltekesos) Bandung \\ lubisyani@ymail.com/yanilbs.stks@gmail.com
}

\begin{abstract}
This research examined the role of community leaders in the empowerment of fisherman family, at Pangandaran village, as a planner, mover, organizer and controller, in order to be able to meet the fisherman family basically needs, to reach the resources of the productive and able to participate in the development process and the decisions making. This research used qualitative descriptive method, with four community leaders as informant and three head of fisherman family, with in-depht interview, observation and dokumentation study. The results showed that the role of community leaders in the fisherman family empowerment had run well. The empowerment formulated based on assessment, explored the needs and the problems of the fisherman familiy and cooperated with some stake holders, informes of rastra and sembako provision, skill training practicing the productive economic businesses, developed the tourism service businesses and provision free of charge home for the fisherman family who become the member of KUD. The successfull of community leaders in the empowerment of fisherman family supported by the internal factors, such as the high motivatios and working experience and the external factors such as the community supported still used the indigenious vallues (gotong rorong)and high care of people and supported by stake holders Pangandaran village, such as the head of Pangandaran district, the ex Minister of the sea and the tourism service stake holder.
\end{abstract}

Key words:

The role of community leaders, Empowerment, Fisherman family

\begin{abstract}
Abstrak
Penelitian ini mengkaji Peran Tokoh Masyarakat dalam Pemberdayaan Keluarga Nelayan di Desa Pangandaran, Kecamatan Pangandaran, Kabupaten Pangandaran, yaitu sebagai perencana, penggerak, pengorganisasi dan sebagai pengontrol, agar keluarga nelayan mampu memenuhi kebutuhan dasarnya, menjangkau sumber-sumber produktif dan mampu berpartisipasi dalam proses pembangunan dan pengambilan keputusan. Penelitian ini menggunakan metode deskriptif kualitatif, dengan informan 4 orang tokoh masyarakat dan 3 orang kepala keluarga dengan Wawancara Mendalam, Observasi dan studi dokumentasi. Hasil penelitian menunjukkan bahwa peran tokoh masyarakat dalam pemberdayaan keluarga nelayan sudah berjalan dengan baik. Program pemberdayaan dirumuskan berdasarkan hasil asesmen, menggali kebutuhan dan permasalahan keluarga nelayan dan bekerja sama dengan berbagai pihak terkait, berupa pemberian rastra dan sembako, latihan keterampilan usaha ekonomi produktif, mengembangkan usaha jasa pariwisata dan pemberian rumah gratis bagi yang menjadi anggota KUD. Keberhasilan pelaksanaan peran tokoh masyarakat tersebut didukung oleh faktor internal seperti motivasi yang tinggi dan pengalaman kerja serta faktor eksternal yaitu dukungan dari
\end{abstract}


masyarakatnya yang masih memegang nilai-nilai gotong royong dan kepedulian yang tinggi terhadap warga masyarakat yang lainnya, serta adanya dukungan dari pejabat daerah Kabupaten Pangandaran (Bupati Pangandaran) dan pejabat yang cukup berpengaruh yaitu mantan Menteri Kelautan serta pejabat dari Dinas Pariwisata.

\section{Kata Kunci:}

Peran Tokoh Masyarakat, Pemberdayaan, Keluarga Nelayan.

\section{PENDAHULUAN}

Pangandaran merupakan salah satu wilayah yang terdapat di Jawa Barat, terkenal sebagai daerah wisata dengan keindahan pantainya dan penghasil ikan. Banyak wisatawan yang berkunjung, baik wisatawan domestik maupun wisatawan mancanegara. Pantai Pangandaran serta objek-objek wisata lainnya yang terdapat di sekitar Pangandaran merupakan daya tarik yang luar biasa bagi para wisatawan untuk berkunjung.

PAD (Pendapatan Asli Daerah) pemerintah Kabupaten Pangandaran cenderung meningkat dari kedua sektor tersebut, dan ini berpengaruh terhadap taraf kehidupan penduduknya. Namun hal tersebut tidak berdampak pada kehidupan nelayan tradisional atau buruh nelayan, mereka masih tetap miskin. Hal ini disebabkan karena distribusi pendapatan yang tidak merata antara kelompok nelayan ini dengan kelompok juragan nelayan atau pemilik modal dan alat penangkap ikan.

Berdasarkan rekap data estimasi capaian indikator Kabupaten Pangandaran tahun 2016 sebanyak 30.418 warga Pangandaran hidup di bawah garis kemiskinan atau sekitar 25\% dari jumlah penduduk (406.898 jiwa atau $131.878 \mathrm{KK}$ ). Kepala Bidang Penelitian, Pengembangan, dan Statistik Badan Perencanaan Pembangunan Daerah (Bappeda) Kabupaten Pangandaran Rohaeni mengatakan, angka kemiskinan tahun 2016 mencapai 7,70 persen dari jumlah penduduk 400.428 jiwa. Grafik kemiskinan yang terjadi di Kabupaten Pangandaran sejak tahun 2013 hingga 2016 masuk kategori fluktuatif. Pada estimasi capaian indikator tahun 2013, angka kemiskinan jatuh pada angka 32.209 jiwa atau 8,34 persen. Pada tahun 2014 angka kemiskinan jatuh pada 30.418 jiwa atau 7,83 persen, sedangkan pada tahun 2015 angka kemiskinan jatuh pada angka 32.686 atau 8,37, dan 2016 jatuh pada angka 31.552 jiwa atau 8,03 persen (Sindo News.com).

Selanjutnya Kepala Bidang Penelitian, Pengembangan, dan Statistik Badan Perencanaan Pembangunan Daerah (Bappeda) Kabupaten Pangandaran menjelaskan bahwa program pengentasan kemiskinan saat ini (tahun 2016) berupa raskin (rastra) gratis, kesehatan gratis, dan pendidikan gratis (Sindo News.com). Program tersebut belum bisa menekan angka kemiskinan. Oleh karena itu diperlukan program pemberdayaan keluarga 
nelayan, yang diarahkan pada penguatan kapasitas keluarga nelayan, agar keluarga nelayan dapat meningkatkan pendapatannya, tidak lagi selalu tergantung pada pemilik modal, mereka bisa keluar dari kemiskinan.

Sebagaimana pelaksanaan kegiatan pemberdayaan keluarga miskin di Indonesia, maka program pemberdayaan keluarga nelayan di Pangandaran ini juga memerlukan keterlibatan tokoh masyarakat setempat. Peran serta tokoh masyarakat sangat diperlukan dalam pemberdayaan keluarga nelayan yang menjadi warganya, mengingat tokoh masyarakat ini merupakan orang-orang yang mengetahui kondisi warganya. Keberhasilan program pemberdayaan keluarga miskin sangat dipengaruhi oleh adanya dukungan dari tokoh masyarakat. Keberdayaan kelompok sasaran ini sangat dipengaruhi oleh dukungan tokoh masyarakat setempat.

Beberapa hasil penelitian menunjukkan bahwa selama ini dukungan dan perhatian dari pemerintah desa terhadap program pemberdayaan keluarga miskin belum maksimal, seperti hasil penelitian Nurhayati (2017) yang telah dilakukan di RW07 Desa Cimenyan, Kabupaten Bandung. Demikian pula dengan hasil penelitian Lubis (2018) bahwa peran tokoh masyarakat dalam pemberdayaan PRSE di Desa Sukamulya, Kecamatan Singaparna, Kabupaten Tasikmalaya juga belum maksimal, sehingga belum bisa membuat PRSE di wilayah tersebut menjadi berdaya, mereka belum mampu memanfaatkan program pemberdayaan yang telah diberikan. Banyak hal yang mempengaruhi mengapa belum maksimal peran tokoh masyarakat dalam pemberdayaan warga masyarakatnya yang masuk kelompok miskin ini. Faktor kurang memahami konsep pemberdayaan itu sendiri lebih dominan, disamping faktor kurang memahami perannya sebagai tokoh masyarakat yang disebabkan masa kerjanya relatif baru, serta kurang dukungan sumber daya manusia dan anggaran.

Fenomena tersebut menjadi daya tarik bagi peneliti untuk mengkaji lebih jauh tentang peran tokoh masyarakat dalam pemberdayaan keluarga nelayan di Pangandaran. Mengingat jumlah keluarga nelayan di Desa Pangandaran ini cukup banyak, dan dikhawatirkan bila mereka tidak diberdayakan dapat menimbulkan permasalahan yang semakin kompleks. Sementara di wilayah tersebut terdapat potensi yang dapat dimanfaatkan untuk mengangkat kehidupan mereka, didukung dengan keberadaan tokoh masyarakat setempat sebagai pihak yang masih memiliki pengaruh besar bagi warganya.

Secara umum, penelitian ini bertujuan puntuk mengkaji tentang Peran Tokoh Masyarakat dalam Pemberdayaan Keluarga Nelayan di Desa Pangandaran, Kecamatan Pangandaran, Kabupaten

Pangandaran. Secara khusus, tujuan penelitian ini untuk mengkaji tentang: 1) Karakteristik informan; 2) Peran tokoh masyarakat sebagai perencana dalam pemberdayaan keluarga nelayan; 3) 
Peran tokoh masyarakat sebagai penggerak dalam pemberdayaan keluarga nelayan; 4) Peran tokoh masyarakat sebagai pengorganisasi dalam pemberdayaan keluarga nelayan; 5) Peran tokoh masyarakat sebagai pengontrol dalam pemberdayaan keluarga nelayan; dan 6) Harapan tokoh masyarakat dalam pelaksanaan peran pemberdayaan keluarga nelayan.

Peran secara umum dimaknai sebagai sesuatu yang dilakukan seseorang berdasarkan status atau kedudukannya di lingkungannya. Peran merupakan aspek dinamis dari kedudukan/status. Bila seseorang melaksanakan hak dan kewajibannya sesuai dengan kedudukannya, maka ia menjalankan suatu peran Soekanto (2017). Peran berkaitan dengan perilaku seseorang di dalam masyarakat, yang menggambarkan kedudukan atau statusnya di dalam masyarakat tersebut, berupa pelaksanaan fungsi, tugas dan kewajibannya. Hal ini sesuai dengan pendapat Suhardono (2016), bahwa peran merupakan seperangkat patokan, yang membatasi apa perilaku yang mesti dilakukan seseorang yang menduduki suatu posisi.

Jadi dapat disimpulkan bahwa peran merupakan pola perilaku yang diharapkan dari seseorang yang memiliki kedudukan atau status sesuai dengan norma yang berlaku dalam masyarakat. Kaitannya dengan penelitian ini, maka tokoh masyarakat diharapkan mampu menunjukkan perilaku yang sesuai dengan kedudukan sebagai orang yang di“tokoh"kan dalam masyarakatnya. Perilaku yang ditampilkan harus sesuai dengan apa yang diharapkan oleh masyarakat, yang banyak dipengaruhi oleh budaya yang terdapat di masyarakat setempat.

Pelaksanaan peran seseorang dapat dipengaruhi oleh banyak hal, bisa karena faktor yang yang ada pada dari diri orang yang bersangkutan maupun karena faktor di luar diri orang yang bersangkutan, seperti yang dijelaskan Effendy (2014). Ada dua faktor yang dapat mempengaruhi pelaksanaan peran seseorang, yaitu: 1) Faktor internal, seperti: usia, pendidikan, pekerjaan dan motivasi; dan 2) Faktor eksternal seperti: lingkungan sosial, fasilitas dan media. Berdasarkan pendapat Effendy tentang faktor-faktor yang dapat mempengaruhi pelaksanaan peran tersebut, maka dapat disimpulkan bahwa keberhasilan pelaksanaan peran pada setiap orang, termasuk pelaksanaan peran tokoh masyarakat dalam pemberdayaan keluarga nelayan juga sangat dipengaruhi keberadaan faktor tersebut.

Peran tokoh masyarakat yang diteliti berkaitan dengan gambaran dari fungsi dan tugasnya yang mengacu pada pendapat Mansyur (2019) yaitu: 1) Fungsi Merencanakan. Seorang tokoh masyarakat tentunya merasa berkewajiban dalam tugasnya di dalam masyarakat, maka harus bisa merencanakan segala sesuatunya di dalam masyarakat. Misalnya, dalam merencanakan terciptanya kesejahteraan pada warganya, keamanan maupun hal lainnya dalam masyarakatnya. 2) Fungsi Mengontrol. Tugas mengontrol erat 
kaitannya dengan pelaksanaan dari suatu kesepakatan bersama/rencana bersama, yaitu meminimalkan kesalahan. Tokoh masyarakat harus mampu bertindak tegas agar warganya tidak berbuat kesalahan-kesalahan kembali serta mau membimbingnya kembali agar kesepakatan-kesepakatan/rencana bersama tersebut dapat berjalan dengan baik. 3) Fungsi Menggerakkan. Menggerakkan merupakan hal terpenting yang harus dilakukan oleh tokoh masyarakat, sebab walaupun rencana tersusun dengan baik dan orangorang maupun perlengkapan telah terorganisir rapih, tetapi apabila tokoh masyarakat tidak mampu menggerakkan, maka rencana tidak dapat berjalan dengan baik. Fungsi menggerakkan ini berkaitan erat dengan kemampuan berkomunikasi tokoh masyarakat tersebut. 4) Fungsi Mengorganisasi. Fungsi ini mengarah kepada pengelompokan sumber-sumber yang ada di wilayahnya, baik sumber manusia maupun non manusia dalam rangka mencapai tujuan bersama, termasuk mengorganisasi sumbersumber dalam rangka mengatasi masalah. Jadi, peran tokoh masyarakat yang dimaksud dalam penelitian ini menyangkut: sebagai perencana, penggerak, pengorganisasi dan peran sebagai pengontrol dalam pemberdayaan keluarga nelayan.

Pengertian tokoh masyarakat berkaitan dengan konsep kepemimpinan. Kepemimpinan merupakan kegiatan mempengaruhi orang-orang agar mereka mau bekerja sama untuk mencapai tujuan yang diinginkan (Suharto, 2017). Kepemimpinan merupakan kegiatan mempengaruhi orang-orang agar mereka mau berusaha mencapai tujuan kelompok (Terry dalam Suharto, 2017). Kepemimpinan juga dimaknai sebagai seni untuk mempengaruhi tingkah laku manusia, kemampuan untuk membimbing orang (Hoyt dalam Soekanto, 2017). Klasifikasi kepemimpinan dibedakan menjadi dua jenis, yaitu: 1) Pemimpim Formal, yaitu: orang yang oleh organisasi/lembaga tertentu ditunjuk sebagai pemimpin berdasarkan keputusan dan pengangkatan resmi untuk memangku suatu jabatan dalam struktur organisasi dengan segala hak dan kewajiban yang berkaitan dengannya untuk mencapai sasaran organisasi. 2) Pemimpin Informal, yaitu: orang yang tidak mendapatkan pengangkatan formal sebagai pemimpin, namun karena ia memiliki sejumlah kualitas unggul, dia mencapai kedudukan sebagai orang yang mampu mempengaruhi kondisi psikis dan perilaku suatu kelompok atau masyarakat (Hoyt dalam Soekanto, 2017).

Jadi, yang dimaksud tokoh masyarakat adalah pemimpin informal, karena statusnya sebagai pemimpin tidak didasarkan atas pengangkatan formal, namun diterima sebagai pemimpin karena kualitasnya mampu mempengaruhi orang lain. Mereka ditokohkan karena memiliki pengaruh/wibawa/kharisma dihadapan masyarakatnya. Ada beberapa ciri yang menunjukkan bahwa seseorang 
merupakan tokoh masyarakat yang membedakannya dengan anggota masyarakatnya sebagaimana yang dikemukakan Hanafi (2020:113-114), yaitu: 1) Tokoh masyarakat memiliki hubungan sosial lebih luas daripada pengikutnya. Mereka lebih sering berhadapan dengan media massa, lebih sering mengadakan perjalanan keluar dan lebih sering berhubungan dengan agen pembaharu. 2) Tokoh masyarakat memiliki keahlian atau pengetahuan tertentu melebihi orang kebanyakan, terutama pengikutnya. Salah satu cara untuk memperoleh pengetahuan dan keahlian itu adalah dengan jalan membuka pintu bagi masuknya ide-ide baru, dan pintu masuk itu adalah hubungan dengan dunia luar. 3) Tokoh masyarakat tidak menyimpan pengetahuan dan keahlian itu untuk diri sendiri, melainkan berusaha untuk menyebarkannya kepada orang lain. Mereka menjadi tumpuan bertanya dan meminta nasihat.

\begin{tabular}{ll}
\multicolumn{2}{c}{ Pelaksanaan peran tokoh } \\
masyarakat dalam penelitian ini \\
ditujukan dalam pemberdayaan \\
keluarga nelayan di Desa Pangandaran,
\end{tabular}
Kecamatan Pangandaran, Kabupaten Pangandaran. Pemberdayaan disini mengacu pada konsep pemberdayaan dari Suharto (2017:58) yang menjelaskan bahwa: pemberdayaan menunjuk pada kemampuan orang, khususnya kelompok rentan dan lemah, sehingga mereka memiliki kekuatan atau kemampuan dalam: 1) memenuhi kebutuhan dasarnya, sehingga mereka memiliki kebebasan (freedom), dalam arti bukan saja bebas mengemukakan pendapat, melainkan bebas dari kelaparan, bebas dari kebodohan, bebas dari kesakitan; 2) menjangkau sumbersumber produktif yang memungkinkan mereka dapat meningkatkan pendapatannya dan memperoleh barangbarang dan jasa-jasa yang mereka perlukan; dan 3) berpartisipasi dalam proses pembangunan dan keputusankeputusan yang mempengaruhi mereka.Graig dan Mayo dalam Huraerah (2018:82) yang menerangkan bahwa konsep pemberdayaan termasuk dalam pengembangan masyarakat dan terkait dengan konsep-konsep: kemandirian (self-help), partisipasi (participation), jaringan kerja (networking) dan pemerataan (equity). Sedangkan menurut Soetarso dalam Huraerah (2018:82-83), pemberdayaan masyarakat pada hakikatnya mempunyai dua pengertian yang saling berkaitan, yaitu: 1) Peningkatan kemampuan, motivasi dan peran semua unsur masyarakat agar dapat menjadi sumber yang langgeng untuk mendukung semua bentuk usaha kesejahteraan sosial; dan 2) Pemanfaatan sumber masyarakat yang telah ditingkatkan kemampuan, motivasi dan perannya.

Pengertian nelayan identik dengan orang yang mata pencahariannya mencari ikan di laut. Hal ini juga bisa dilihat dari pengertian nelayan yang terdapat dalam Pasal 1 (10) UU No.45 Tahun 2009 tentang Perikanan, bahwa Nelayan adalah orang yang mata pencahariannya melakukan penangkapan ikan. Nelayan merupakan 
suatu kelompok masyarakat yang kehidupannya tergantung langsung pada hasil laut, baik dengan cara melakukan penangkapan atau pun budidaya. Mereka pada umumnya tinggal di pinggir pantai, sebuah lingkungan pemukiman yang dekat dengan lokasi kegiatannya (Imron dalam Mulyadi, 2007).

Nelayan bukanlah suatu entitas tunggal, mereka terdiri dari beberapa kelompok (Imron dalam Mulyadi, 2007). Dilihat dari segi kepemilikan alat tangkap, nelayan dapat dibedakan menjadi tiga kelompok, yaitu nelayan buruh, nelayan juragan dan nelayan perorangan. Nelayan buruh adalah nelayan yang bekerja dengan alat milik orang lain. Sebaliknya nelayan juragan adalah nelayan yang memiliki alat tangkap yang dioperasikan oleh orang lain. Adapun nelayan perorangan adalah nelayan yang memiliki alat tangkap sendiri, dan dalam pengoperasiannya tidak melibatkan orang lain.

Nelayan digolongkan menjadi empat tingkatan yang dilihat dari kapasitas teknologi (alat tangkap dan armada), orientasi pasar, dan karakteristik hubungan produksi, yaitu: 1) Peasant-fisher atau nelayan tradisional yang biasanya lebih berorientasi pada kebutuhan sendiri (subsisten), nelayan ini mengalokasikan hasil jual tangkapannya untuk memenuhi kebutuhan sehari-hari dan bukan diinvestasikan untuk pengembangan skala usaha; 2) Post-fisher yaitu nelayan yang telah menggunakan teknologi penangkap ikan yang lebih maju seperti motor tempel atau kapal motor.
Penguasaan sarana perahu motor semakin membuka peluang nelayan untuk menangkap ikan di wilayah perairan yang lebih jauh dan memperoleh surplus dari hasil tangkapan tersebut karena mempunyai daya tangkap yang lebih besar. Pada jenis ini, nelayan sudah berorientasi pasar.; 3) Commercial-fisher yaitu nelayan yang telah berorientasi pada peningkatan keuntungan. Skala usahanya sudah besar dan dicirikan dengan banyaknya jumlah tenaga kerja dan dicirikan dengan status tenaga kerja yang beragam, dari buruh hingga manajer. Teknologi yang digunakan lebih modern sehingga diperlukan keahlian tersendiri dalam pengoperasiannya; dan 4) Industrialfisher (Satria, 2015). Ciri nelayan industri adalah: 1) Diorganisasi dengan cara-cara yang mirip dengan perusahaan argoindustri di negara-negara maju; 2) Secara relatif lebih padat modal; 3) Memberi pendapatan yang lebih tinggi daripada perikan serderhana, baik untuk pemilik maupun awak kapal; dan 4) Menghasilkan untuk ikan kaleng dan ikan beku yang berorientasi ekspor (Pollnac dalam Satria, 2015).

Nelayan yang menjadi sasaran TPI (Tempat Pelelangan Ikan) sendiri sepertinya terbatas kepada nelayan tradisional (peasant-fisher) dan postfisher. Kepemilikan alat tangkap dapat menunjukkan tingkat pendapatan seorang nelayan. Pendapatan yang berbeda akan menghasilkan pola pikir yang berbeda dalam memandang suatu kebutuhan. Masyarakat pesisir seringkali memiliki kesempatan yang lebih rendah 
dalam mengakses pemenuhan kebutuhan dasarnya seperti pendidikan, kesehatan dan pemenuhan sarana produksi usahanya sehingga terkadang kondisi sosial ekonominya relatif masih rendah (Hanson dalam Amanah dkk, 2005).

\section{METODE}

Penelitian ini menggunakan metode deskriptif dengan pendekatan kualitatif. Metode deskriptif digunakan untuk mendapatkan gambaran secara faktual mengenai Peran Tokoh Masyarakat dalam Pemberdayaan Keluarga Nelayan di Desa Pangandaran, Kecamatan Pangandaran, Kabupaten Pangandaran. Metode deskriptif adalah pencarian fakta dengan interpretasi yang tepat (Whitney dalam Nazir, 2019).

Pendekatan kualitatif digunakan agar dapat memperoleh gambaran dari obyek yang diteliti secara utuh atau menyeluruh, sebagaimana yang dikemukakan Sugiyono (2017) bahwa metode penelitian naturalistik/kualitatif digunakan untuk meneliti pada tempat yang alamiah dan peneliti tidak membuat perlakuan, karena peneliti dalam mengumpulkan data bersifat emic, yaitu berdasarkan pandangan dari sumber data, bukan pandangan peneliti. Maksudnya bahwa penelitian kualitatif adalah suatu proses penelitian yang alamiah, secara utuh, tidak ada perlakuan dari peneliti. Peneliti membangun suatu gambaran yang kompleks dan menyeluruh, menganalisa kata-kata dari semua informan berdasarkan sudut pandang informan, tentang perannya sebagai tokoh masyarakat dalam pemberdayaan keluarga nelayan selama ini, serta melakukan penelitian pada latar yang alamiah, di lokasi dimana informan berada tanpa ada rekayasa atau settingan sebelumnya.

Latar yang digunakan dalam penelitian ini yaitu: latar tertutup, seperti tempat kediaman informan (rumah di luar dan di dalam perumahan nelayan) dan ruangan kantor tempat informan bekerja sehari-hari (kantor desa dan Kantor Dinas Pariwisata Pangandaran), dan latar terbuka seperti lokasi sekitar wilayah informan biasa melakukan pengawasan di lingkungan pasar sekitar pantai Pangandaran dengan sumber data primer adalah tokoh masyarakat Desa Pangandaran, Kecamatan Pangandaran, Kabupaten Pangandaran sebanyak 4 orang dan kepala keluarga nelayan Desa Pangandaran, Kecamatan Pangandaran, Kabupaten Pangandaran sebanyak 3 orang. Penentuan informan ini dilakukan secara purposive (bertujuan), didasarkan pada kriteria berikut: 1) Tokoh masyarakat formal dan informal; 2) Penduduk Desa Pangandaran, Kecamatan Pangandaran; 3) Memiliki pengalaman dalam kegiatan pemberdayaan keluarga nelayan di Desa Pangandaran, Kecamatan Pangandaran, Kabupaten Pangandaran; dan 4) Paling lama menjadi Tokoh Masyarakat informal. Penentuan informan ini dilakukan atas petunjuk dari orang yang paling mengetahui keberadaan informan, dengan pertimbangan informan juga terbuka dalam memberikan informasi yang dibutuhkan. Penentuan informan lainnya yaitu kepala keluarga nelayan 
melalui bantuan koordinator himpunan nelayan yang banyak mengetahui keberadaan keluarga nelayan di wilayah Desa Pangandaran, Kecamatan Pangandaran, Kabupaten Pangandaran, yang lokasinya mudah dijangkau.

Teknik pengumpulan data yang digunakan dalam penelitian ini adalah: Wawancara Mendalam (in-depth Interview), mengajukan sejumlah pertanyaan yang tidak berstruktur berdasarkan pedoman wawancara; observasi dengan mengamati lingkungan tempat kediaman informan, kondisi kehidupan keluarganya dan aktivitas informan sehari-hari sebagai nelayan dengan mengacu pada pedoman observasi; dan studi dokumentasi dengan mempelajari profil desa Pangandaran. Pemeriksaan keabsahan data dilakukan mengacu pada pendapat Sugiyono (2017), yaitu dengan uji credibility, untuk melihat tingkat kepercayaan terhadap data hasil penelitian, melalui: member Check, mempertegas kembali data yang telah diberikan oleh informan dan triangulasi, memperjelas data atau informasi dari informan kepada pihak lain yang paling mengetahui kehidupan informan. Berikutnya, melakukan uji Transferability, untuk melihat derajat kepercayaan terhadap data hasil penelitian dengan cara membuat uraian yang rinci, jelas, sistematis dan dapat dipercaya pada laporan hasil penelitian, sehingga dapat diputuskan dapat/tidaknya hasil penelitian diaplikasikan di tempat lain. Selanjutnya, melakukan uji Dependability, untuk melihat keajegan (reliabilitas) data hasil penelitian dengan cara mengaudit keseluruhan proses penelitian oleh auditor independen atau pembimbing dan uji Confirmability, untuk melihat objektivitas data hasil penelitian dengan cara menyampaikan hasil penelitian melalui forum ilmiah tertentu, agar diperoleh kesepakatan dari banyak orang. Kemudian, data yang diperoleh dianalisis secara kualitatif, dilakukan secara terus menerus sejak awal dan selama proses penelitian berlangsung, dengan menginterpretasikannya secara naratif dengan cara: reduksi data, kategorisasi dan pengkodean, display data dan kesimpulan.

\section{HASIL PENELITIAN \\ Karakteristik informan}

Informan dalam penelitian tentang Peran Tokoh Masyarakat dalam Pemberdayaan keluarga nelayan di Desa Pangandaran, Kecamatan Pangandaran, Kabupaten Pangandaran ini yaitu empat orang tokoh masyarakat dan tiga orang kepala keluarga nelayan. SR, pria berusia 51 tahun, beragama Islam, PJS (Pejabat sementara) Kepala Desa Pangandaran, lulusan SMA. SR tidak begitu banyak terlibat dalam kegiatan pemberdayaan keluarga nelayan di Desa Pangandaran, karena baru menjabat sampai menunggu terpilihnya kepala desa yang baru.

JS, pria berusia 54 tahun, beragama Islam, dengan jabatan sebagai Sekretaris Kepala Desa Pangandaran berpendidikan. JS berpendidikan SMA dan sudah lama bekerja di kantor Desa 
Pangandaran, yaitu sekitar 19 tahun. JS sudah sering terlibat dalam kegiatan pemberdayaan keluarga nelayan di Desa Pangandaran.

LK, perempuan usia 54 tahun beragama Islam, dengan jabatan sebagai Sekretaris Kepala Dinas Pariwisata Pangandaran. LK lulusan S1 STKS (Sekolah Tinggi Kesejahteraan Sosial) Bandung dan banyak berperan dalam pembangunan pariwisata Pangandaran. LK juga banyak terlibat dalam kegiatan pemberdayaan keluarga nelayan Desa Pangandaran, sehingga sangat dikenal oleh tokoh masyarakat Desa Pangandaran.

$\mathrm{AD}$, pria berusia 53 tahun, beragama Islam, berpendidikan SMA dengan jabatan sebagai Koordinator HNSI (Himpunan Nelayan Seluruh Indonesia) cabang Pangandaran. AD juga sebagai ketua "Satgas Jaga Lembur" Desa Pangandaran, yang membawahi; 5) RM, pria berusia 57 tahun, beragama Islam, kepala keluarga nelayan yang mendapatkan bantuan rumah; 6) SG, pria berusia 71 tahun kepala keluarga nelayan, beragama Islam, berpendidikan SR (Sekolah Rakyat), pernah menjadi anggota KUD nelayan, namun saat ini sudah keluar karena tidak mampu membayar simpanan wajib dan sudah tidak memiliki perahu, sudah dijual.

\section{Peran Tokoh Masyarakat sebagai Perencana}

Peran tokoh masyarakat sebagai perencana, merencanakan program kegiatan yang tepat untuk memberdayakan keluarga nelayan. Perencanaan dibuat berdasarkan analisis kebutuhan dan sistem sumber yang tersedia, dengan melakukan asesment terlebih dahulu. Dipelajari apa yang menjadi permasalahan keluarga nelayan, mengapa tidak bisa keluar dari rantai kemiskinan. Target pelaksanaan peran tokoh masyarakat sebagai perencana ini diarahkan kepada target pemberdayaan keluarga nelayan yang mengacu pada pendapat Suharto (2015), yaitu: kemampuan memenuhi kebutuhan dasar, menjangkau sumber-sumber produktif dan kemampuan berpartisipasi dalam proses pembangunan dan pengambilan keputusan.

\section{Peran Tokoh Masyarakat sebagai Perencana agar Keluarga Nelayan Mampu Memenuhi Kebutuhan Dasar}

Program pemberdayaan keluarga nelayan di Desa Pangandaran dirumuskan sedemikian rupa berdasarkan hasil asesmen terlebih dahulu. Tokoh masyarakat beserta jajarannya mempelajari, mengamati dan menggali apa yang menjadi masalah dan kebutuhan warga masyarakatnya. Hasil asesmen tersebut menjadi pertimbangan untuk menyusun bentuk kegiatannya.

Mengingat warga masyarakatnya yang berprofesi sebagai nelayan tradisional, dimana permasalahannya berkaitan dengan ketidakmampuan dalam memenuhi kebutuhan dasar, terutama di saat tidak melaut, maka program yang dirancang berupa pemberian bantuan beras miskin (raskin) atau yang sekarang dikenal dengan 
istilah beras sejahtera (rastra). Bantuan raskin/rastra diberikan secara gratis kepada keluarga nelayan yang sudah menjadi anggota Koperasi Unit Desa "Mina Sari" (KUD) Desa Pangandaran. Selain bantuan raskin/rastra, keluarga nelayan yang menjadi anggota KUD juga akan mendapat bantuan lainnya, seperti kebutuhan pokok lainnya dan bantuan pinjaman uang.

Keluarga nelayan yang sudah menjadi anggota KUD akan mendapatkan bantuan kebutuhan dasar berupa raskin/rastra setiap bulan April, yang diberikan untuk mengantisipasi musim tidak melaut, yang disebut "dana paceklik". Sedangkan keluarga nelayan yang belum menjadi anggota KUD, tidak mendapat bantuan raskin/rastra dari KUD. Bantuan pemenuhan kebutuhan dasarnya dan bantuan yang lainnya didapat dari juragannya, yang besarnya sesuai dengan kesepakan sebelumnya, biasanya berupa bagi hasil dari hasil tangkapannya dengan menggunakan perahu juragan nelayan.

Keluarga nelayan yang sudah menjadi anggota KUD akan mendapatkan bantuan kebutuhan dasar berupa raskin/rastra setiap bulan April, yang diberikan untuk mengantisipasi musim tidak melaut, yang disebut "dana paceklik". Bantuan raskin/rastra diberikan kepada keluarga nelayan yang sudah menjadi anggota KUD pada saat nelayan tidak melaut, karena gelombang laut sangat tinggi. Selain raskin/rastra, keluarga nelayan yang menjadi anggota KUD juga menerima bantuan sembako lainnya dan pinjaman uang, karena dana
KUD terhimpun dari iuran wajib anggotanya.

Keluarga nelayan yang belum menjadi anggota KUD, tidak mendapat bantuan raskin/rastra dari KUD. Bantuan pemenuhan kebutuhan dasarnya dan bantuan yang lainnya didapat dari juragannya, yang besarnya sesuai dengan kesepakan sebelumnya, biasanya berupa bagi hasil dari hasil tangkapannya dengan menggunakan perahu juragan nelayan. Selain itu, tokoh masyarakat juga mengupayakan keluarga nelayan yang belum atau tidak menjadi anggota KUD mendapat bantuan pemenuhan kebutuhan dasarnya berupa bantuan sembako gratis dari program Kementerian Kelautan.

Berdasarkan informasi yang disampaikan beberapa tokoh masyarakat tersebut, maka dapat disimpulkan bahwa tokoh masyarakat Desa Pangandaran sudah melaksanakan perannya sebagai perencana agar keluarga nelayan mampu memenuhi kebutuhan dasarnya. Tokoh masyarakat merencanakan akan memberikan bantuan raskin/rastra dan kebutuhan pokok lainnya kepada keluarga nelayan yang sudah menjadi anggota KUD pada saat tidak melaut. Sedangkan, keluarga nelayan yang belum atau tidak menjadi anggota KUD direncanakan akan diupayakan mendapat sembako gratis dari program Kementerian Kelautan dan dari bagi hasil dengan juragannya. 
Peran Tokoh Masyarakat sebagai Perencana agar Keluarga Nelayan Mampu Menjangkau SumberSumber Produktif

Sumber merupakan segala sesuatu yang dapat dimanfaatkan untuk membantu memenuhi kebutuhan dan mengatasi masalah. Adakalanya orang tidak mengetahui adanya sumbersumber yang bisa dimanfaatkan untuk memenuhi kebutuhan atau mengatasi masalahnya, atau ada yang mengetahui keberadaan sumber tersebut, namun tidak mampu menjangkaunya. Termasuk keluarga nelayan, mereka tidak mengetahui dan tidak mampu menjangkau sumber yang dapat membantu memenuhi kebutuhan atau mengatasi masalahnya. Oleh karena itu, tokoh masyarakat merencanakan membantu keluarga nelayan agar mengetahui dan dapat menjangkau sumber dengan mengenalkan dan menjelaskan sumber-sumber yang dimaksud serta membantu strategi menjangkaunya. Seperti KUD, yang bisa dimanfaatkan untuk memenuhi kebutuhan hidup sehari-hari, termasuk ketika tidak bisa melaut.

Persyaratan yang dimaksud yaitu: memiliki perahu, memiliki alat tangkap ikan dan wajib membayar iuran. Anggota KUD akan mendapat bantuan raskin/rastra setiap bulan April, membantu mengatasi ekonomi keluarga nelayan saat musim tidak melaut, yang disebut dengan dana paceklik. Selain itu, KUD juga menyediakan kebutuhan pokok yang bisa dibeli anggotanya dengan harga terjangkau, serta menyediakan peluang untuk pinjaman uang.

Berikutnya, ada kelompok nelayan yang sudah maju, bisa dimanfaatkan keluarga nelayan untuk meningkatkan pengetahuan dan keterampilan menangkap hasil laut. Tokoh masyarakat juga merencanakan melibatkan Dinas Perindustrian dan Perdagangan dalam pemberdayaan keluarga nelayan, dengan mengenalkan kepada keluarga nelayan peluang untuk meningkatkan keterampilan mengolah hasil tangkapan di laut menjadi sebuah produk yang bernilai ekonomis, seperti: udang krispi, ikan krispi, cumi-cumi krispi dan jenis kuliner lainnya, serta membuat ikan asin jambal dan terasi dari udang rebon yang berkualitas dan banyak diminati pembeli. Selanjutnya, keberadaan pasar yang sudah dipusatkan di satu lokasi. Keluarga nelayan dapat memanfaatkan pasar sebagai tempat berjualan, khususnya bagi isteri nelayan untuk menambah penghasilan keluarga. Berdasarkan penjelasan tersebut, dapat disimpulkan bahwa tokoh masyarakat Desa Pangandaran juga sudah menjalankan perannya sebagai perencana agar keluarga nelayan mengetahui dan mampu menjangkau sumber-sumber produktif, dengan mengenalkan dan membantu keluarga nelayan menjangkau sumber-sumber tersebut, seperti KUD, nelayan yang sudah maju, Dinas Perindustrian dan Perdagangan serta pasar yang bisa dimanfaatkan keluarga nelayan untuk berjualan, yang sebelumnya berjualan di tepi pantai. 
Peran Tokoh Masyarakat sebagai Perencana agar Keluarga Nelayan Mampu Berpartisipasi dalam Proses Pembangunan dan Pengambilan Keputusan

Pemberdayaan keluarga nelayan yang dilakukan tokoh masyarakat juga diarahkan pada kemampuan dalam berpartisipasi dalam pembangunan dan pengambilan keputusan. Tokoh masyarakat merencanakan pelibatan keluarga nelayan dalam setiap kegiatan, untuk mengkondisikan keluarga nelayan berpartisipasi dalam pembangunan dan dalam pengambilan keputusan, menyampaikan ide atau gagasannya. Keluarga nelayan dilibatkan dalam kegiatan merancang program pemberdayaan dan dalam pengambilan keputusan. Hal ini dimaksudkan agar keluarga nelayan dapat menyampaikan langsung pendapat/gagasannya, mengenai program pemberdayaan yang nantinya juga akan ditujukan kepada mereka. Oleh karena itu, penyusunan program dikondisikan sedemikian rupa, dengan melibatkan keluarga nelayan, agar keluarga nelayan mampu menyampaikan apa yang menjadi kebutuhan atau masalahnya.

Informasi yang disampaikan tokoh masyarakat sebagai informan penelitian ini menggambarkan bahwa peran tokoh masyarakat dalam pemberdayaan keluarga nelayan agar mampu berpartisipasi dalam pembangunan dan pengambilan keputusan sudah dilaksanakan dengan melibatkan keluarga nelayan dalam merumuskan program kegiatan berupa penyampaian gagasan/ide atau masukanmasukan yang selanjutnya disepakati bersama menjadi sebuah program pemberdayaan keluarga nelayan.

\section{Peran Tokoh Masyarakat sebagai Penggerak}

Menggerakkan merupakan hal terpenting yang harus dilakukan oleh tokoh masyarakat, sebab walaupun rencana sudah tersusun dengan baik dan sumber daya manusia maupun sarana dan prasarana telah tersedia, namun apabila tokoh masyarakat tidak mampu menggerakkannya, maka rencana tidak dapat berjalan dengan baik. Fungsi menggerakkan ini berkaitan erat dengan kemampuan berkomunikasi tokoh masyarakat tersebut. Oleh karena itu, tokoh masyarakat berupaya menggerakkan seluruh komponen masyarakat dalam pelaksanaan program pembangunan di wilayahnya.

Tokoh masyarakat Desa Pangandaran melakukan berbagai upaya menggerakkan seluruh unsur di masyarakat dalam pemberdayaan keluarga nelayan agar mampu memenuhi kebutuhan dasarnya, menjangkau sumber-sumber produktif serta agar mampu berpartisipasi dalam pembangunan dan dalam pengambilan keputusan. Upaya yang dilakukan tokoh masyarakat berupa memotivasi dan menghimbau agar semua pihak, termasuk keluarga nelayan itu sendiri terlibat dalam pemberdayaan keluarga nelayan. Himbauan yang dilakukan diiringi dengan memotivasi, mendorong agar tumbuh keinginan untuk berubah ke 
arah yang lebih baik lagi, untuk kepentingan semua pihak.

Peran Tokoh Masyarakat sebagai Penggerak agar Keluarga Nelayan Mampu Memenuhi Kebutuhan Dasar

Peran tokoh masyarakat dalam pemberdayaan keluarga nelayan juga sebagai penggerak, menggerakkan semus unsur dalam masyarakat agar keluarga nelayan mampu memenuhi kebutuhan dasarnya. Upaya yang dilakukan Tokoh masyarakat diawali dengan dengan memotivasi dan menghimbau keluarga nelayan agar menjadi anggota KUD, karena dengan menjadi anggota KUD akan mendapat bantuan raskin/rastra dan kebutuhan pokok lainnya.

Sampai saat ini sudah sekitar 700 keluarga nelayan menjadi anggota KUD, selebihnya belum karena tidak memenuhi persyaratan menjadi anggota KUD. Persyaratan menjadi anggota KUD Mina Sari yaitu: memiliki perahu dan memiliki alat penangkap ikan, dan harus membayar simpanan wajib dan simpanan sukarela. Dana dari simpanan anggota KUD Mina Sari ini dikelola oleh pengurusnya sampai dapat memenuhi kebutuhan dasar keluarga nelayan.

Masih ada keluarga nelayan yang belum menjadi anggota KUD, karena tidak memenuhi persyaratan tersebut, sehingga tidak mendapatkan bantuan raskin/rastra dan kebutuhan pokok lainnya dari KUD. Seperti yang dialami NG, perempuan berusia 55 tahun ini tidak menjadi anggota KUD, karena tidak memenuhi persyaratan, sehingga tidak mendapat bantuan apapun dari KUD, walaupun kondisinya sangat memerlukan bantuan pemenuhan kebutuhan dasar. NG menghidupi dirinya dan keponakannya yang penyandang disabilitas rungu wicara dari hasil jualan makanan ringan di depan rumahnya, karena suaminya sudah lama pergi meninggalkan dirinya dan sudah menikah lagi di daerah lain. NG tidak melaut lagi, karena kondisi fisiknya yang sudah tidak kuat karena mengidap penyakit gula dan tidak memiliki peralatan untuk menangkap ikan.

Pengalaman NG ini juga dialami SG, pria berusia 71 tahun ini juga tidak mendapat bantuan apapun dari KUD, karena tidak menjadi anggota KUD. Sebelumnya SG pernah menjadi anggota KUD, namun saat ini sudah keluar karena sudah tidak memiliki perahu dan tidak mampu membayar simpanan wajib. Perahu telah dijual SGuntuk biaya pengobatan isterinya yang saat ini sudah meninggal. Masih beruntung SG, masih ada anak-anaknya sudah berkeluarga dan mandiri, masih membantu kebutuhan sehari-harinya dan masih memiliki jaring penangkap ikan yang sewaktuwaktu masih digunakan bila ombak tidak besar dan kondisi fisiknya sehat.

Tokoh masyarakat juga memotivasi dan menghimbau para isteri nelayan untuk berusaha membantu pendapatan keluarga, terutama pada saat suaminya tidak melaut. Usaha para isteri nelayan selama ini yaitu dengan berjualan nasi, mengolah hasil tangkapan berupa ikan asin atau yang terkenal asin jambal, dan membuat terasi 
dari udang rebon. Selain itu, istri nelayan juga dihimbau untuk berusaha di bidang lainnya, seperti berjualan pakaian dan makanan ringan yang diolah dari bahan baku hasil tangkapan nelayan di laut, seperti udang krispi, ikan krispi dan cumi krispi.

Istri nelayan dimotivasi tokoh masyarakat untuk melakukan kegiatan usaha ekonomis produktif, agar bisa membantu pendapatan keluarga. Keterlibatan isteri nelayan berjualan di pasar, sangat membantu kepala keluarga nelayan dalam menunjang ekonomi keluarga, terutama di masa paceklik atau saat tidak melaut. Selain itu, juga untuk memenuhi kebutuhan wisatawan untuk oleh-oleh yang akan dibawa pulang.

Informasi dari beberapa informan tersebut menggambarkan bahwa peran tokoh masyarakat sebagai penggerak agar keluarga nelayan mampu memenuhi kebutuhan dasarnya sudah dilaksanakan dengan baik, sudah 700 keluarga nelayan menjadi anggota KUD, dan otomatis sudah mendapatkan bantuan kebutuhan dasarnya berupa raskin/rastra dan kebutuhan pokok lainnya. Selain itu, isteri nelayan juga dapat membantu ekonomi keluarga dari hasil berjualan di pasar.

Peran Tokoh Masyarakat sebagai Penggerak agar Keluarga Nelayan Mampu Menjangkau SumberSumber Produktif

Tokoh masyarakat berupaya memotivasi keluarga nelayan agar mampu menjangkau sumber-sumber yang dapat dimanfaatkan untuk menunjang ekonomi keluarga. Keluarga nelayan dimotivasi agar mau berubah dari yang semula hanya sebagai buruh nelayan atau nelayan tradisional, menjadi nelayan yang yang maju, memiliki pengetahuan dan keterampilan dalam menangkap hasil laut yang banyak agar mendapatkan keuntungan yang banyak. Upaya yang dilakukan tokoh masyarakat dengan memotivasi keluarga nelayan agar mau belajar ke juragan nelayan dalam menangkap hasil laut dengan menggunakan alat tangkap ikan yang tepat dan moderen. Hal ini dimaksudkan agar keluarga nelayan dapat meningkatkan keterampilannya menangkap hasil laut dan tidak berfikir negatif pada keberhasilan nelayan lain.

Maksudnya pernyataan tersebut, untuk menyadarkan keluarga nelayan agar tidak timbul kecemburuan sosial terhadap keberhasilan nelayan lainnya. Keluarga nelayan harus mau meningkatkan keterampilannya dalam menangkap hasil laut, dengan mau belajar ke juragan nelayan atau nelayan lain yang sudah berhasil yaitu nelayan pantai Baron. Nelayan di wilayah pantai Baron berhasil menangkap hasil laut yaitu udang dalam jumlah yang banyak, karena sudah menggunakan alat tangkap ikat yang moderen. Mereka sudah memiliki kemampuan dalam penggunaan metode dan strategi yang efektif dalam menangkap hasil laut.

Peran tokoh masyarakat berikutnya yaitu memotivasi dan menghimbau isteri nelayan agar mau mengikuti latihan keterampilan mengolah hasil tangkapan suaminya dari 
laut yang mempunyai nilai tambah agar mudah laku dijual karena menarik minat banyak pembeli. Selanjutnya disampaikan bentuk lain upaya yang dilakukan tokoh masyarakat dalam memberdayakan keluarga nelayan agar mampu menjangkau sumber, yaitu dengan memberi peluang bagi nelayan tradisonal untuk mengembangkan jejaring keluar. Keluarga nelayan diberi kesempatan untuk memasarkan hasil tangkapannya keluar Desa Pangandaran, dengan kewajiban menyerahkan $4 \%$ dari hasil penjualannya ke KUD.

Informasi

tersebut menggambarkan bahwa tokoh masyarakat Desa Pangandaran yang menjadi informan dalam penelitian ini sudah melaksanakan perannya sebagai penggerak dengan baik agar keluarga nelayan mampu menjangkau sumbersumber produktif. Keluarga nelayan dikondisikan agar mau belajar meningkatkan pengetahuan dan keterampilannya kepada nelayan yang sudah berhasil, mengikuti latihan keterampilan usaha ekonomi produktif dan mengembangkan jejaring untuk memasarkan hasil tangkapannya sampai keluar wilayah Pangandaran.

Peran Tokoh Masyarakat sebagai Penggerak agar Keluarga Nelayan Mampu Berpartisipasi dalam Proses Pembangunan dan Pengambilan Keputusan

Pemerintah daerah Pangandaran mencanangkan Desa Pangandaran menjadi daerah wisata pantai. Oleh karena itu, maka daerah pantai di tata sedemikian rupa menjadi kawasan wisata yang nyaman untuk dikunjungi. Tokoh masyarakat menggerakkan semua warganya untuk berpartisipasi mendukung pembangunan Pangandaran sebagai salah satu destinasi wisata di Kabupaten Pangandaran. Upaya yang dilakukan tokoh masyarakat yaitu menghimbau nelayan untuk mau pindah memarkir perahunya di lokasi yang telah disiapkan, yaitu di sekitar pantai barat. Warga masyarakat juga dihimbau untuk tidak berjualan di sekitar pantai, karena sudah disiapkan pasar untuk menampung mereka dan harus menjaga kebersihan dan keamanan pantai Pangandaran.

Pemerintah Daerah Pangandaran membuat kebijakan untuk menjadikan pantai Pangandaran sebagai lokasi wisata. Dilakukan pembangunan yang melibatkan seluruh masyarakat termasuk keluarga nelayan dalam menata wilayah sekitar pantai Pangandaran, agar menjadi lokasi yang menarik untuk dikunjungi para wisatawan. Kebijakan tersebut tidak saja akan mendatangkan keuntungan bagi Pemerintah Daerah pangandaran, tetapi juga bisa mendatangkan keuntungan bagi keluarga nelayan.

Jadi, dapat disimpulkan bahwa tokoh masyarakat Desa Pangandaran sudah melaksanakan perannya sebagai penggerak agar keluarga nelayan mampu berpartisipasi dalam pembangunan dan pengambilan keputusan. Pelibatan langsung keluarga nelayan dalam menata kembali pantai Pangandaran dengan memindahkan lokasi parkir perahu dan menempatkan pedagang ke 
pasar yang telah dipersiapkan serta menjaga kebersihan dan kenyamanan pantai Pangandaran.

\section{Peran Tokoh Masyarakat sebagai Pengorganisasi}

Peran tokoh masyarakat sebagai pengorganisasi yaitu mengorganisir sumber-sumber yang dapat dimanfaatkan untuk pemberdayaan keluarga nelayan di Desa Pangandaran, agar keluarga nelayan dapat memenuhi kebutuhan dasarnya, agar mampu menjangkau sumber-sumber produktif serta agar keluarga nelayan mampu berpartisipasi dalam pembangunan dan pengambilan keputusan. Upaya yang dilakukan tokoh masyarakat dengan membangun kesepakatan bersama dalam bentuk kerja sama dengan instansi atau pihak-pihak yang terkait untuk melakukan kegiatan pemberdayaan keluarga nelayan.

\section{Peran Tokoh Masyarakat sebagai Pengorganisasi agar Keluarga Nelayan Mampu Memenuhi} Kebutuhan Dasar

Pelaksanaan peran tokoh masyarakat sebagai pengorganisasi agar keluarga nelayan mampu memenuhi kebutuhan dasarnya dilakukan dengan mengorganisir sumber-sumber terkait yang telah diidentifikasi berdasarkan kebutuhan. Tokoh masyarakat membangun kerja sama dengan pengusaha atau pedagang beras yang memenuhi kriteria sebagai penyalur raskin/rastra melalui sistem lelang, yaitu: yang kualitas berasnya bagus dan tercatat sebagai pembayar pajak yang baik. Sistem lelang dengan persyaratan tersebut dimaksudkan agar jelas dan mudah dalam pengelolaannya dan untuk menghindari hal-hal yang tidak diinginkan, seperti adanya persaingan yang tidak sehat di kalangan pedagang beras, serta adanya jaminan mengenai kualitas beras yang bagus.

Sumber lain yang dimanfaatkan tokoh masyarakat agar keluarga nelayan mampu memenuhi kebutuhan dasarnya yaitu Kementerian Kelautan dengan Ibu Susi sebagai Menteri Kelautannya, putera daerah Pangandaran yang berperan besar dalam pembangunan Pangandaran sebagai kawasan wisata juga dalam pemberdayaan keluarga nelayan. Kementerian Kelautan memberi bantuan sembako gratis kepada keluarga nelayan yang belum menjadi anggota KUD.

Tokoh masyarakat juga bekerja sama dengan beberapa instansi lainnya dan pihak-pihak yang terkait dalam pemberdayaan keluarga nelayan agar mampu memenuhi kebutuhan dasarnya, seperti Dinas Perindustrian dan Perdagangan, serta Dinas Pariwisata. Pelibatan Dinas Perindustrian dan Perdagangan serta Dinas Pariwisata ini dalam rangka membina isteri nelayan meningkatkan keterampilannya mengolah hasil tangkapan di laut agar menghasilkan usaha ekonomi produktif dan mengembangkan usaha jasa pariwisata, seperti menyewakan rumahnya untuk para wisatawan yang berkunjung ke pantai Pangandaran. Hasilnya dapat menambah penghasilan 
keluarga dalam memenuhi kebutuhan dasarnya.

Informasi

tersebut

menggambarkan bahwa tokoh masyarakat Desa Pangandaran sudah menjalankan perannya dengan baik sebagai pengorganisasi agar keluarga nelayan mampu memenuhi kebutuhan dasarnya. Dilakukan kerja sama dengan berbagai pihak, seperti pengusaha/pedagang beras yang menang lelang, Dinas Perindustrian dan Perdagangan serta Dinas Pariwisata, dengan membina isteri nelayan agar memiliki keterampilan usaha ekonomi produktif dan mengembangkan usaha jasa pariwisata untuk menambah penghasilan keluarga.

\section{Peran Tokoh Masyarakat sebagai Pengorganisasi agar Keluarga Nelayan Mampu Menjangkau Sumber-Sumber Produktif}

Peran tokoh masyarakat sebagai pengorganisasi disini yaitu mengorganisir sumber yang terkait agar keluarga nelayan mampu menjangkau sumber-sumber produktif. Upaya yang dilakukan tokoh masyarakat Desa Pangandaran yaitu membangun kerja sama dengan beberapa kementerian dan pihak-pihak terkait yang bisa membantu pemberdayaan keluarga miskin. Sumber yang diorganisir tokoh masyarakat untuk memberdayakan keluarga nelayan agar mampu menjangkau sumber-sumber produktif yaitu Dinas Pariwisata Pangandaran, dengan membina kelompok usaha bersama isteri nelayan mengolah hasil tangkapan di laut berupa cemilan udang krispi, ikan krispi, cumicumi krispi, ikan asin jambal dan terasi dari udang rebon, yang bisa dimanfaatkan untuk membantu ekonomi keluarga, terutama untuk mengantisipasi saat suaminya tidak melaut.

Selain itu, Dinas Pariwisata juga berusaha mendorong keluarga nelayan untuk mengembangkan usahanya, dari usaha nelayan ke usaha jasa pariwisata, seperti menyewakan rumah untuk wisatawan yang berkunjung, berjualan makanan dan pakaian khas pantai Pangandaran di pasar. Sumber lain yang dimanfaatkan yaitu Dinas Perindustrian dan Perdagangan untuk mengembangkan usaha keluarga nelayan agar bisa menambah penghasilan keluarga nelayan. Dinas Perindustrian dan Perdagangan membina usaha home industry yang selama ini sudah ada namun belum terkenal yaitu pembuat gula nipah, serupa dengan gula merah yang dibuat dari pohon nipah, yang memiliki khasiat untuk kesehatan. Dibina kemasannya semenarik mungkin dan strategi pemasarannya agar mempunyai nilai jual yang tinggi. Usaha handy craft berupa hiasan dari limbah tangkapan di laut juga dibina agar menghasilkan produk hiasan menarik yang bernilai jual tinggi.

Kebutuhan dasar keluarga nelayan tidak saja beras dan bahan sembako lainnya, melainkan juga rumah sebagai tempat tinggal. Tokoh masyarakat bekerja sama dengan Pemerintah Daerah Pangandaran dan Kementerian Pekerjaan Umum dan Perumahan Rakyat (PUPR) 
memfasilitasi pengadaan rumah untuk keluarga nelayan. Pada tahap pertama dan kedua sudah dibangun 100 unit rumah dan pada tahap ketiga akan dibangun 72 unit rumah. Perumahan "Kampung Nelayan" ini sudah ditempati oleh anggota KUD sebanyak 172 keluarga nelayan, sedangkan yang tidak atau belum menjadi anggota KUD tidak mendapatkan rumah, walaupun kondisinya sangat membutuhkan bantuan rumah. Di sekitar kompleks perumahan "Kampung Nelayan" ini disiapkan dan ditata sungai Cikidang untuk parkir perahu nelayan bagi nelayan yang menempati perumahan tersebut.

Informasi dari beberapa
informan tersebut menggambarkan
bahwa tokoh masyarakat Desa
Pangandaran sudah menjalankan perannya sebagai pengorganisasi agar keluarga nelayan mampu menjangkau sumber-sumber produktif. Pelibatan langsung Dinas Prindustrian dan Perdagangan, Dinas Pariwisata, Dinas PUPR serta Pemerintah Daerah Pangandaran.

Peran Tokoh Masyarakat sebagai Pengorganisasi agar Keluarga Nelayan Mampu Berpartisipasi dalam Proses Pembangunan dan Pengambilan Keputusan

Peran tokoh masyarakat Desa Pangandaran sebagai pengorganisasi dalam pemberdayaan keluarga nelayan juga diarahkan kepada kemampuan keluarga nelayan berpartisipasi dalam pembangunan dan pengambilan keputusan. Tokoh masyarakat melibatkan keluarga nelayan dalam kegiatan program pembangunan Desa Pangandaran, khususnya program pemberdayaan keluarga nelayan. Seperti saat diadakan musrembang tentang pembentukan Kelompok Pengelola dan Pemasaran Ikan (Poklasar), yang terdiri dari kelompok nelayan budi daya ikan air tawar dan air payau serta budi daya ikan tambak. Pembinaan Poklasar ini dilakukan dalam bentuk pengembangan kapasitas nelayan dengan melibatkan Dinas Perikanan untuk melakukan pelatihan dan pemberian bantuan peralatan menangkap ikan.

Upaya tokoh masyarakat mengorganisir sumber agar keluarga nelayan mampu berpartisipasi dalam pembangunan dan pengambilan keputusan juga dilakukan dalam bentuk pelibatan keluarga nelayan dalam menata pantai Pangandaran untuk menjadi kawasan wisata. Bekerja sama dengan Dinas Pariwisata merelokasi tempat berjualan ke pasar yang sudah dipersiapkan dan merelokasi tempat parkir perahu nelayan ke pantai Barat. Keluarga nelayan mendukung program tersebut dan turut berpartisipasi menjaga kebersihan dan kenyamanan pantai Pangandaran.

Informan

tersebut, menggambarkan bahwa tokoh masyarakat Desa Pangandaran sudah menjalankan perannya sebagai pengorganisasi agar keluarga nelayan berpartisipasi dalam pembangunan dan pengambilan keputusan. Keluarga nelayan diikutsertakan dalam kegiatan 
musrembang menyusun poklasar (kelompok pengelola pemasaran ikan), dan pelibatan keluarga nelayan dalam menjaga kebersihan dan kenyamanan pantai Pangandaran.

\section{Peran Tokoh Masyarakat sebagai Pengontrol}

Peran tokoh masyarakat sebagai pengontrol dimaksudkan mengontrol jalannya kegiatan pemberdayaan keluarga nelayan, memantau pelaksanaan kegiatan dan perkembangannya, mengamati kendala yang dan peluang yang bisa dimanfaatkan untuk mengatasi kendala agar tujuan program kegiatan tercapai. Upaya yang dilakukan tokoh masyarakat dalam mengontrol jalannya kegiatan pemberdayaan keluarga nelayan ini difokuskan pada kemampuan keluarga nelayan memenuhi kebutuhan dasarnya, menjangkau sumber-sumber produktif serta berpartisipasi dalam pembangunan dan pengambilan keputusan.

Peran Tokoh Masyarakat sebagai Pengontrol agar Keluarga Nelayan Mampu Memenuhi Kebutuhan Dasar Peran tokoh masyarakat sebagai pengontrol dalam kegiatan pemberdayaan keluarga nelayan agar mampu memenuhi kebutuhan dasarnya dilakukan dengan mengawal proses pelaksanaannya. Dilibatkan Dinas Sosial dalam memastikan kualitas raskin/rastra dan penyalurannya tepat sasaran dan jumlahnya sesuai dengan ketentuan pemerintah. Selain itu, tokoh masyarakat juga melibatkan Kepolisian untuk memastikan proses pembagian raskin/rastra tersebut berlangsung tertib dan aman. Sistem kontrol yang dibangun tokoh masyarakat dalam kegiatan pemberdayaan keluarga nelayan agar mampu memenuhi kebutuhan dasarnya dengan mengamati langsung proses pelaksanaannya dan juga dari laporan pertanggungjawaban pihak yang bertanggung jawab dalam pelaksanaan kegiatan.

Informasi tersebut menunjukkan bahwa tokoh masyarakat Desa Pangandaran sudah melaksanakan perannya sebagai pengontrol pada kegiatan pemberdayaan keluarga nelayan agar mampu memenuhi kebutuhan dasarnya. Pelibatan pihak Dinas Sosial, kepolisian dan melalui laporan kegiatan maupun dari pengamatan langsung tokoh masyarakat yang bersangkutan.

Peran Tokoh Masyarakat sebagai Pengontrol agar Keluarga Nelayan Mampu Menjangkau SumberSumber Produktif

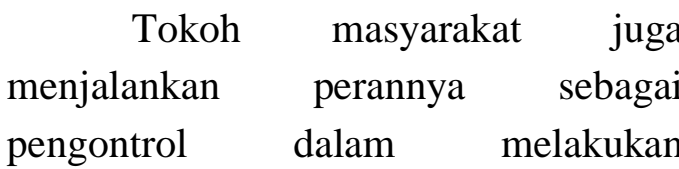
pemberdayaan keluarga nelayan agar mampu menjangkau sumber-sumber produktif. Upaya yang dilakukan tokoh masyarakat dengan selalu mensosialisasikan program pemberdayaan tersebut melalui berbagai media, seperti media sosial dan media "hajatan desa". Maksudnya, semua pihak termasuk warga masyarakat atau keluarga nelayan mengetahui 
keberadaan program pemberdayaan tersebut, proses pelaksanaannya dan perkembangannya. Hal ini bisa dijadikan sebagai alat untuk mengontrol keberlangsungan program.

Informasi tersebut menunjukkan bahwa pelaksanaan peran tokoh masyarakat sebagai pengontrol terhadap program pemberdayaan keluarga nelayan agar mampu menjangkau sumber juga sudah berjalan dengan baik. Mekanismenya dengan sosialisasi proram menggunakan media sosial dan media "hajatan desa", agar semua pihak mengetahui dan ikut mengawasi pelaksanaan program tersebut dan perkembangannya.

Peran Tokoh Masyarakat sebagai Pengontrol agar Keluarga Nelayan Mampu Berpartisipasi dalam Proses Pembangunan dan Pengambilan Keputusan

Pelaksanaan peran tokoh

masyarakat dalam pemberdayaan keluarga nelayan agar mampu berpartisipasi dalam pembangunan dan pengambilan keputusan dilakukan dengan melibatkan warga masyarakat, khususnya para pemuda yang dipandang cakap, kuat dan memiliki kemampuan khusus mendampingi keluarga nelayan berpartisipasi dalam membangun pantai Pangandaran sebagai kawasan wisata. Strateginya dengan membentuk kelompok masyarakat untuk menjaga keamanan wilayah pantai Pangandaran yaitu "Satgas Jaga Lembur", dengan merekrut pemuda Desa Pangandaran yang kuat fisik, mental dan memiliki keterampilan bela diri yang hebat. Status mereka volunteer, tidak digaji, hanya diberi insentif untuk kepentingan pelaksanaan tugasnya. Keberadaan "Satgas Jaga Lembur" merupakan bentuk sistem kontrol yang dapat menjamin keikutsertaan keluarga nelayan dalam pembangunan dan pengambilan keputusan di wilayah Desa Pangandaran.

Informasi tersebut menunjukkan bahwa tokoh masyarakat Desa Pangandaran sudah menjalankan perannya dalam pemberdayaan keluarga nelayan agar mampu berpartisipasi dalam pembangunan dan dalam pengambilan keputusan. Keberadaan "Satgas Jaga Lembur" sangat membantu pelaksanaan peran tersebut.

\section{Harapan Tokoh Masyarakat dalam Pelaksanaan Peran Pemberdayaan Keluarga Nelayan}

Hasil penelitian menggambarkan bahwa semua tokoh masyarakat yang menjadi informan dalam penelitian ini berharap sama dalam melaksanakan perannya sebagai tokoh masyarakat dalam pemberdayaan keluarga nelayan, baik dalam pelaksanaan perannya sebagai perencana, penggerak, pengorganisasi maupun perannya sebagai pengontrol agar keluarga nelayan mampu memenuhi kebutuhan dasarnya, mampu menjangkau sumbersumber produktif serta mampu berpartisipasi dalam pembangunan dan pengambilan keputusan. Semua Informan berharap agar dukungan dari semua pihak baik moril maupun materil 
terus ditingkatkan, juga ada kemudahan memperluas jejaring dengan sumber lainnya, mengingat kebutuhan dan permasalahan keluarga nelayan juga semakin berkembang. Informan berharap lebih banyak lagi pihak-pihak yang terlibat dalam pemberdayaan keluarga nelayan, baik dari sektor pemerintah maupun swasta atau masyarakat, agar jumlah sasaran dan kualitas pemberdayaan juga bertambah.

\section{PEMBAHASAN}

\begin{tabular}{lrrr}
\multicolumn{2}{c}{ Berdasarkan } & deskripsi hasil \\
penelitian tentang & Peran Tokoh \\
Masyarakat dalam & Pemberdayaan
\end{tabular} Keluarga Nelayan di Desa Pangandaran ini, diketahui bahwa semuanya sudah berjalan dengan baik. Semua tokoh masyarakat yang menjadi informan dalam penelitian ini memberikan gambaran pelaksanaan perannya yang sudah dilaksanakan dengan baik. Peran sebagai perencana, sebagai penggerak, sebagai pengorganisasi dan peran sebagai pengontrol kegiatan pemberdayaan keluarga nelayan agar mampu memenuhi kebutuhan dasarnya, menjangkau sumber-sumber produktif serta agar mampu berpartisipasi dalam pembangunan dan pengambilan keputusan semua sudah dilaksanakan dengan baik. Hal ini juga diketahui dari hasil penggalian informasi dari beberapa kepala keluarga nelayan di wilayah Desa Pangandaran, yang membenarkan informasi dari tokoh masyarakat tersebut.

Hasil pengamatan selama berada di lokasi penelitian juga menggambarkan bahwa tokoh masyarakat Desa Pangandaran sudah melaksanakan perannya dengan baik. Terlihat ada perubahan kondisi kehidupan keluarga nelayan yang menjadi sasaran pemberdayaan, mereka dengan tersenyum menjelaskan pemenuhan kebutuhan dasarnya sudah terpenuhi. Mereka menempati rumah layak huni yang bangunannya tertata dengan rapih, raut bahagia tergambar pada wajah keluarga nelayan ketika ditanya tentang penilaiannya mengenai kondisi rumah yang ditempatinya, demikian pula pancaran bahagia juga terlihat saat isteri nelayan menceritakan bahwa mereka sudah bekerja, pekerjaannya saat ini dapat menambah penghasilan suaminya. Mereka bangga memiliki keterampialan dan hasilnya sudah bisa membantu penghasilan suami.

Keberhasilan tokoh masyarakat Desa Pangandaran dalam memberdayakan keluarga nelayan menggambarkan kemampuannya dalam mempengaruhi semua pihak yang terlibat dalam kegiatan pemberdayaan, termasuk keluarga nelayan itu sendiri sebagai sasaran pemberdayaan. Hal ini sesuai dengan pendapat Suharto (2017), bahwa kepemimpinan merupakan kegiatan mempengaruhi orang-orang agar mereka mau bekerja sama untuk mencapai tujuan yang diinginkan. Sama halnya dengan pendapat Terry dalam Suharto (2019), bahwa kepemimpinan merupakan kegiatan mempengaruhi orang-orang agar mereka mau berusaha mencapai tujuan kelompok. 
Banyak hal yang mempengaruhi kemampuan seseorang melaksanakan perannya, seperti yang dikemukakan oleh Effendy (2014), yaitu faktor internal, seperti: usia, pendidikan, pekerjaan dan motivasi.; dan faktor eksternal seperti: lingkungan sosial, fasilitas dan media. Berdasarkan pendapat Effendy tersebut, maka hampir semua faktor baik faktor internal maupun eksternal mempengaruhi keberhasilan ke empat tokoh masyarakat yang menjadi informan dalam penelitian ini melaksanakan perannya dalam pemberdayaan keluarga nelayan. Faktor internal, seperti usia, semua (empat) tokoh masyarakat Desa Pangandaran yang melakukan pemberdayaan keluarga nelayan berusia di atas 50 tahun, usia yang masuk kategori dewasa ini menggambarkan pengalaman kerja yang sudah lama, juga berpengaruh terhadap pola fikir, sikap dan perilakunya. Faktor pendidikan, ini tidak begitu mempengaruhi kemampuan informan dalam pelaksanaan perannya, karena dari empat informan hanya satu orang yang pendidikannya Sarjana, selebihnya hanya sampai SLTA.

Berikutnya, faktor pekerjaan juga dapat berpengaruh bila pekerjaannya berkaitan dengan peran yang dijalankan, semua informan pekerjaannya berkaitan erat dengan pelaksanaan perannya, yaitu dalam bidang pemberdayaan masyarakat. Faktor motivasi, motivasi yang tinggi melaksanakan peran sangat berpengaruh terhadap keberhasilan pelaksanaan peran. Semua informan dapat dikatakan memiliki motivasi yang tinggi dalam melaksanakan perannya, karena pekerjaannya di bidang pemberdayaan masyarakat dalam hal ini keluarga nelayan.

Faktor selanjutnya yaitu faktor eksternal, seperti lingkungan sosial. Lingkungan sosial masyarakat di Desa Pangandaran masih kuat nilai persaudaraannya, nilai gotong royongnya, dan tinggkat kepeduliannya juga masih tinggi, sehingga ini memudahkan tokoh masyarakat melakukan pemberdayaan keluarga nelayan, karena banyak pihak yang mendukung, termasuk keluarga nelayan itu sendiri. Kemudian faktor fasilitas, tokoh masyarakat melakukan pemberdayaan keluarga nelayan difasilitasi oleh pihak-pihak yang mendukung kegiatan tersebut, dukungan dari orang yang berpengaruh di Pangandaran, seperti Menteri Kelautan (ibu Susi). Selain itu, dukungan dari Bupati Pangandaran cukup besar dalam pelaksanaan peran tokoh masyarakat dalam pemberdayaan keluarga nelayan. Demikian pula dengan dukungan dari pejabat Dinas Pariwisata, ini bisa juga mempengaruhi pelaksanaan peran tokoh masyarakat dalam melakukan kegiatan pemberdayaan keluarga nelayan.

Jadi, dapat disimpulkan bahwa keberhasilan tokoh masyarakat yang menjadi informan dalam penelitian ini melaksanakan perannya melakukan pemberdayaan keluarga nelayan dipengaruhi oleh banyak faktor, baik dari faktor internal maupun dari faktor eksternal. Faktor yang paling signifikan 
mempengaruhi pelaksanaan peran tokoh masyarakat tersebut adalah dari faktor internal, seperti: faktor motivasi, pekerjaan dan usia. Sedangkan dari faktor eksternal adalah faktor lingkungan sosial berupa dukungan dari pejabat yang mempunyai pengaruh yang kuat. Berbeda dengan hasil penelitian Lubis sebelumnya tahun 2018 tentang peran tokoh masyarakat dalam pemberdayaan PRSE di Desa Sukamulya Kecamatan Singaparna Kabupaten Tasikmalaya yang menunjukkan kurang berhasil, disebabkan karena tidak adanya faktor internal dan eksternal yang mendukung keberhasilan pelaksanaan peran tokoh masyarakat. Hasil penelitian menunjukkan bahwa PRSE masih belum berdaya, masih menganggur dan tergantung pada bantuan.

Meskipun tokoh masyarakat Desa Pangandaran sudah melaksanakan perannya memberdayakan keluarga nelayan dengan baik, namun perlu dilakukan upaya untuk mempertahankan dan atau meningkatkan kualitas pemberdayaan, sehingga keluarga nelayan terus berdaya, dapat menjalankan fungsi sosialnya sebagaimana mestinya. Keberdayaan keluarga nelayan ini juga dapat memperluas peluang keluarga nelayan lainnya untuk mendapatkan kesempatan mendapatkan program pemberdayaan, sehingga diharapkan bisa mengentaskan kemiskinan keluarga nelayan di Desa Pangandaran, Kecamatan Pangandaran, Kabupaten Pangandaran. Oleh karena itu, maka perlu perlu melibatkan Pekerja
Sosial dalam melakukan pendampingan pemberdayaan keluarga nelayan Pangandaran. Selain itu, diharapkan Pemerintah Daerah Pangandaran membangun kerja sama yang lebih luas lagi dengan banyak kementrian untuk mendukung keberhasilan pelaksanaan peran tokoh masyarakat melakukan pemberdayaan keluarga nelayan di Desa pangandaran.

\section{KESIMPULAN}

Hasil penelitian tentang Peran Tokoh Masyarakat dalam Pemberdayaan Keluarga Nelayan di Desa Pangandaran ini, menggambarkan pelaksanaan peran tokoh masyarakat yang sudah berjalan dengan baik. Ke empat informan penelitian ini dari segi usia semuanya berusia di atas 50 tahun, pekerjaannya ada yang menjadi PJS Kepala Desa, Sekretaris Desa, Sekretaris Kepala Dinas Pariwisata dan Koordinator HNSI (Himpunan Nelayan Seluruh Indonesia). Sedangkan, dari latar pendidikannya hanya satu orang yang Sarjana; dan satu orang ini perempuan, selebihnya laki-laki.

Tokoh masyarakat sebagai informan dalam penelitian ini sudah melaksanakan perannya dengan baik dalam pemberdayaan keluarga nelayan, baik peran sebagai perencana, penggerak, pengorganisasi maupun peran sebagai pengontrol. Hasilnya dapat dilihat dari beberapa indikator perubahan pada keluarga nelayan yang menjadi sasaran pemberdayaan tersebut, yaitu: kemampuan keluarga nelayan memenuhi kebutuhan dasarnya, 
walaupun belum semua keluarga nelayan yang ada di Desa Pangandaran, baru yang menjadi anggota KUD saja. Kemudian kemampuan keluarga nelayan menjangkau sumber-sumber produktif serta kemampuan keluarga nelayan berpartisipasi dalam pembangunan dan pengambilan keputusan.

Keberhasilan informan dalam pelaksanaan perannya melakukan pemberdayaan keluarga nelayan ini dipengaruhi oleh faktor motivasi yang tinggi memberdayakan keluarga nelayan, bidang pekerjaannya yang memang di bidang pemberdayaan masyarakat dan faktor usia yang menunjukkan pengalaman kerja yang lama di bidang tersebut, sehingga sangat menguasai bidang pekerjaannya. Berikutnya, faktor lingkungan sosial yang mendukung, masyarakatnya masih memegang nilai-nilai persaudaraan, gotong royong dan kepedulian yang tinggi terhadap warga masyarakat, serta adanya dukungan dari pejabat daerah Kabupaten Pangandaran (Bupati Pangandaran), pejabat yang cukup berpengaruh yaitu Menteri Kelautan (ibu Susi) dan pejabat dari Dinas Pariwisata.

Hasil penelitian ini diharapkan berimplikasi pada pemerintah daerah

\section{DAFTAR PUSTAKA}

Hanafi, Abdillah. (2020). Memasyarakatkan Ide-Ide Baru. Surabaya: Usaha Nasional.

Huraerah, Abu. (2018). Pengorganisasian dan

Pengembangan Masyarakat, Model dan Strategi Pembangunan dalam merumuskan kebijakan untuk meningkatkan kualitas pemberdayaan keluarga nelayan dengan meningkatkan kompetensi tokoh masyarakat, pengembangan jejaring di sektor pemerintah dan sektor swasta atau dunia usaha dan meningkatkan anggaran untuk memfasilitasi kegiatan pemberdayaan keluarga nelayan. Hasil penelitian ini juga diharapkan berimplikasi pada meningkatnya kemandirian keluarga nelayan dan meningkatnya partisipasi masyarakat dengan tetap melestarikan nilai-nilai kearifan lokal masyarakat nelayan. Selain itu, perlu pelibatan profesi pekerjaan sosial dalam pemberdayaan keluarga untuk melakukan pendampingan, agar hasil pemberdayaan dapat berkesinambungan. Hasil penelitian ini selanjutnya berimplikasi terhadap dunia akademisi, dengan mengembangkan konsep atau teori pemberdayaan dengan memperhatikan aspek lain sebagai penentu keberhasilan pemberdayaan keluarga nelayan, yaitu kompetensi dan fasilitasi pihak yang terlibat dalam pemberdayaan, dalam hal ini tokoh masyarakat. Disamping itu, pemanfaatan nilai-nilai kearifan lokal juga menjadi salah satu penentu keberhasilan pemberdayaan keluarga nelayan.

Berbasis Kerakyatan. Bandung: Humaniora.

Satria, Arif. (2015). Pengantar Sosiologi Masyarakat Pesisir. Jakarta: Yayasan Pustaka Obor Indonesia.

Mansyur, Cholil. (2019). Sosiologi Masyarakat Kota dan Desa. Surabaya: Usaha Nasional. 
Suharto, Edi. (2015). Membangun Masyarakat Memberdayakan Rakyat. Bandung: PT. Refika Aditama.

(2017). Pekerjaan Sosial di Dunia Industri. Bandung: PT. Refika Aditama. ..(2019). Analisis Kebijakan Publik: Panduan Praktis Mengkaji Masalah dan Kebijakan Sosial (edisi ke-4). Bandung: Alfabeta.

Suhardono, Edy. (2016). Teori Peran: Konsep, Derivasi dan Implikasi. Jakarta: PT. Gramedia Pustaka Utama.

Glossaries Pekerjaan Sosial.(2004). Bandung: Sekolah Tinggi Kesejahteraan Sosial (STKS).

Lubis, Nurhayani. (2018). Peran Tokoh Masyarakat dalam Pemberdayaan Perempuan Rawan Sosial Ekonomi (PRSE) di Desa Sukamulya, Kecamatan Singaparna, Kabupaten Tasikmalaya. Hasil penelitian. Bandung: Sekolah Tinggi Kesejahteraan Sosial (STKS).

Nazir, Moh. (2019). Metode Penelitian. Jakarta: Ghalia Indonesia.

S, Mulyadi. (2007). Ekonomi Kelautan. Jakarta: PT Raja Grafindo Persada.

Umar, Musni. (2013). Tanggung jawab Pemimpin dan Tokoh Masyarakat terhadap Rakyat dan Pembangunan. Materi presentasi pada program Kesbangpol Jakarta. Diakses dari http://musniumar.wordpress.com.

Effendy, Onong Uchjana. (2014). Dinamika Komunikasi. Bandung: PT. Remaja Rosdakarya.

Soekanto, Soerjono.(2017). Sosiologi Suatu pengantar. Jakarta: Rajawali. Sugiyono.(2017). Metode Penelitian Kuantitatif, Kualitatif dan $R \& D$. Bandung: Alfabeta.

Taslimin.(2015). Peran Tokoh Masyarakat Dalam Corporate Social Responsibility (CSR) di PT Aneka Tambang (Tbk) Kecamatan Maba, Kabupaten Halmahera Timur, Provinsi Maluku Utara. Karya Ilmiah Akhir (KIA). Bandung: Sekolah Tinggi Kesejahteraan Sosial (STKS).

Undang-Undang No.45 Tahun 2009 tentang Perikanan.

Nurhayati, Wahyu.(2017). Advokasi Program Pemberdayaan Perempuan Keluarga Miskin di Kabupaten Bandung. Jurnal Ilmiah Pekerjaan Sosial vol. 16 No.2, Juni: hal 302-324. 